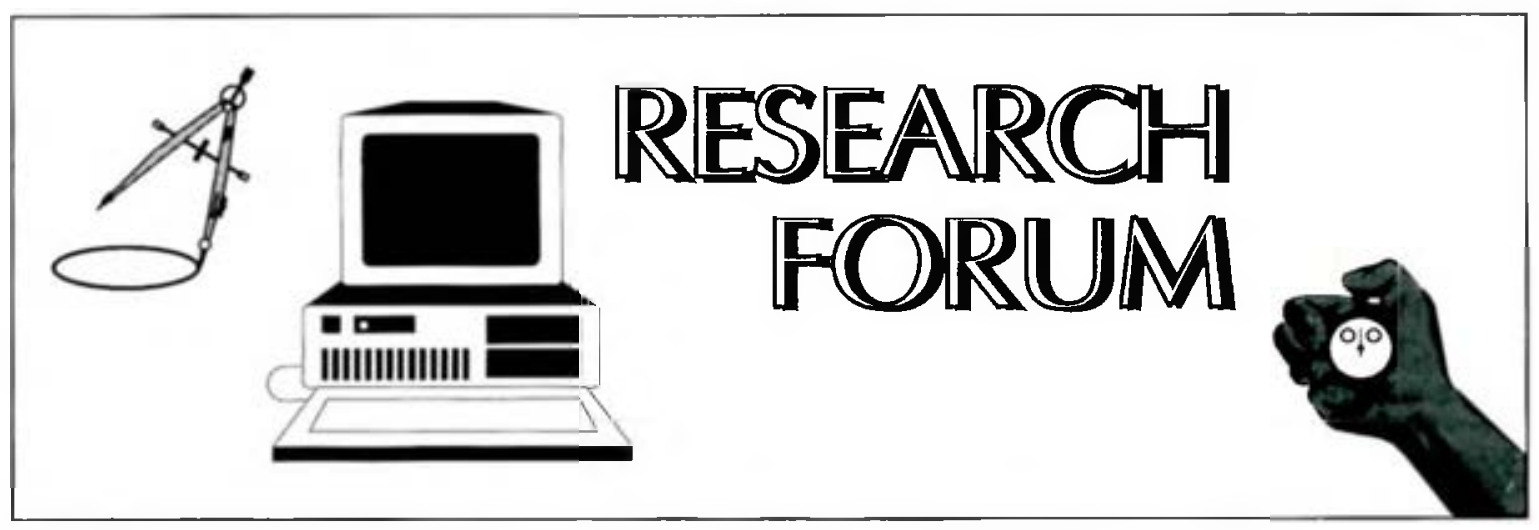

\title{
Fostering research activity: Examples of institutional support
}

\author{
By Bonnie Gratch \\ Head of Reference \\ Bowling Green State University
}

In relation to the June 1989 "Research Forum" article, which reported the findings of a survey of California State University and University of California librarians' research and publishing activities, I solicited copies of statements or policies that describe types of institutional support provided for such activities. I received only two responses, from which comments are included below. Since the intent is to focus attention on approaches that may be of interest to library professional development committees and administrators, I have included additional examples and ideas taken from the Association of Research Libraries' SPEC Kit \#86, Professional Development in ARL Libraries (1982); a handout, "Creating a Supportive Environment for Research," prepared by Maureen Pastine and presented at the ACRL postconference, "Inspiring Enthusiasm for Research," April 8-9, 1989, in Cincinnati, Ohio; and the policy statement on research support at Bowling Green State University Libraries.

\section{Release time}

All sources examined reveal that formal policies or guidelines are needed that describe the philosophy and procedures to support research and publishing. Also essential is an organized group (e.g., committee on library research, library professional development committee, research and publication committee, etc.), whose charge includes such activities as: promoting research and publication; soliciting proposals for research release time and funding; establishing criteria and reviewing proposals. Examples in the SPEC Kit make it clear that release time, (exclusive of faculty improvement leave or sabbatical leaves conferred by the university or college), arrangements are varied and often require some negotiation with various administrative levels. Release time for research and publication activities is frequently viewed as time reassigned from the primary job assignment. In many cases it is approved by the immediate supervisor for rather short-term periods contingent on the overall staffing situation in the unit and the merit of the research request. Bowling Green State University Libraries policy allows supervisors to approve release time requests for up to four hours a week, while the library faculty development committee makes decisions on research release time and funding requests for larger time periods.

Release time awards are ordinarily limited to a cumulative total of 160 hours (about one month), although this limit may be exceeded with the approval of the supervisor and the dean of the libraries. York University's library director sent a copy of a section from the "Collective Agreement Between the Board of Governors of York University and the York University Faculty Association," which discusses release time. It states that "workload for 
librarians shall be established with due regard for their research and scholarly responsibilities. Release time shall be made available within the scheduling of the normal work week, so that librarians may pursue research and scholarly work."

Another example illustrates the concept of "unassigned time" that is available as part of the normal work week to support research and publishing activities. Ohio State University Libraries' document, "Guidelines for Assigned and Unassigned Time and for Assigned Research Duty," contained in the SPEC Kit, defines "assigned time" as not less than $80 \%$ of the work week that is to be devoted to performing the functions of the position, as well as attendance and preparation for service activities and attendance and participation in professional meetings which directly aid or develop job performance. "Unassigned time" is defined as not more than $20 \%$ of the work week which may be spent on research, preparation for library, university and professional service obligations, professional development activities, and community service. Accountability measures are also included. In addition to the unassigned time option, a special allocation of time called "assigned research duty" exists which frees a library faculty member from regularly assigned duty to work on a particularly meritorious research project for which the unassigned time option is not adequate to meet the needs of the researcher.

\section{Funding options}

Some libraries set aside a pool of money from the library's operating budget to support research

\section{Attention, authors!}

\section{College \& Research Libraries News wel-} comes manuscripts submitted on diskette or via ALANET. The C\&RL News ALANET number is ALA0306. If you prefer to send a diskette, make sure it is formatted for MS-DOS; either 5.25-inch or 3.5-inch diskettes can be accepted.

We use Xywrite III + for word processing, but we translate files from other major programs. When submitting a diskette with a file created by another word processing program, it is best to also include an ASCII text file. Always send a paper copy of your manuscript along with the diskette, just in case we cannot read your file.

If you can neither send a diskette nor transmit via ALANET, submit three paper copies in a standard typeface such as Courier or Pica. Submit all materials to George M. Eberhart, Editor, CむRL News, ACRL/ALA, 50 E. Huron St., Chicago, IL 60611.-GME. needs. Another fairly common resource is the university-wide professional development and research support committees' funds to which librarians may make application for awards of money to support research and professional development activities. Academic librarians whose libraries are part of state systems or are represented by unions may also be able to apply for research support funds from these sources. Of course, professional associations, foundations, and government agencies are typically included in research support statements as another possible funding source for research support through grant programs. The chair of the library faculty task force on staff development at the State University of New York-Buffalo submitted a recent document on research support that identified such potential funding sources as grant overhead funds and the university committee on institutional funds. In her presentation Pastine suggested the following funding ideas: designating a percentage of the library's endowment funds; using part of the indirect cost recovery monies from grants; and using salary savings.

\section{Take a broad view of the work environment}

SUNY-Buffalo's research support document and Pastine's presentation illustrate the importance of broadly viewing the types of campus resources and facilities that can benefit research and publishing activities. The SUNY-Buffalo document contains a four-page chart listing a variety of library and campus resources and facilities, from computing services to typesetting services. Pastine identified types of activities and resources grouped by collegial contact, operational, and educational. Collegial contact activities include those which stimulate thought, creativity and enthusiasm for research; such as colloquia or brown-bag discussion series, mentoring arrangements, brainstorming sessions, and visiting lecturers. Operational sources are types of support that the library or university provides as part of its operation; such as use of equipment, online searches, and clerical support. Educational resources include tuitionwaivers and release time to pursue degree or nondegree continuing education opportunities.

As with most worthwhile endeavors, the key ingredients seem to be an institutional commitment to facilitating research and scholarly endeavors; a clear plan which describes the philosophy, policies and procedures for research and scholarly activities; the involvement of library faculty and administrators in implementing and refining the plan; and effective communication to all librarians about the broad range of library, campus, and even external resources that may be viewed as part of a supportive research environment. 